SOSIOLIUM

\title{
IMPLEMENTASI PENDIDIKAN MULTIKULTURAL PEMBELAJARAN ILMU PENGETAHUAN SOSIAL DI SMP N 30 SEMARANG
}

\author{
Muhammad Lutfi, Puji Lestari ${ }^{\circledR}$ \\ Prodi Pendidikan IPS, Fakultas Ilmu Sosial, Universitas Negeri Semarang, Indonesia
}

\begin{tabular}{l}
\hline Info Artikel \\
\hline Sejarah Artikel: \\
Disubmit: Juli 2021 \\
Direvisi: Agustus 2021 \\
Diterima: September \\
2021 \\
\hline
\end{tabular}

Keywords:

Implementation,

Multicultural, Multicultural

Education Based Learning,

Social Studies.

\begin{abstract}
Abstrak
SMP Negeri 30 Semarang merupakan sekolah yang menerapkan pendidikan multikultural, sehingga perlu dikaji lebih mendalam mengenai implementasi pendidikan multikultural dalam pembelajaran IPS. Penelitian ini menggunakan metode penelitian kualitatif. Hasil penelitian menunjukan bahwa: (1) Implementasi pendidikan multikultural dalam pembelajaran IPS di SMP Negeri 30 Semarang diawali dengan perencanaan pembelajaran. Pelaksanaan pembelajaran bersifat terbuka, demokratis, berpusat pada peserta didik yang menekankan pada kesetaraan dan keadilan peserta didik serta menghargai masing-masing individu. Evaluasi pembelajaran mengarah pada kognitif, efektif dan psikomotorik dengan menggunakan instrumen sendiri dalam menilai sikap multikultural. (2) Faktor pendukung dalam pelaksanaan pendidikan multikultural yaitu lingkungan dan iklim sekolah, materi dan metode pembelajaran, progam dan kegiatan sekolah, ekstrakurikuler (bakat dan minat), serta keasadaran peserta didik. Faktor penghambat dalam yaitu keterbatasan materi IPS tentang keragaman, keterbatasan media tentang keragaman, masih terdapat beberapa peserta didik yang mengejek temannya, minimnya papan-papan maupun tulisan tentang keragaman.
\end{abstract}

\begin{abstract}
SMP Negeri 30 Semarang is a school that implements multicultural education, so it needs to be studied more deeply about at the implementation of multicultural education in social studies learning. This study used qualitative research methods. The results showed that: (1) The implementation of multicultural education in social studies learning at SMP Negeri 30 Semarang begins with lesson planning. The implementation of learning is open, democratic, student-centered which emphasizes the equality and fairness of students and respects each individual. Learning evaluation leads to cognitive, effective and psychomotor by using their own instruments in assessing multicultural attitudes. (2) Supporting factors in the implementation of multicultural education, namely the school environment and climate, learning materials and methods, school programs and activities, extracurricular activities (talents and interests), and the awareness of students. Inhibiting factors are the limitations of social studies material on diversity, media limitations on diversity, there are still some students who mock their friends, the lack of boards or writing about diversity.
\end{abstract}

(C) 2021 Universitas Negeri Semarang

\footnotetext{
Alamat korespondensi:

Gedung C1 Lantai 1 FIS Unnes

Kampus Sekaran, Gunungpati, Semarang, 50229

E-mail: puji.lestari@mail.unnes.ac.id
} 


\section{PENDAHULUAN}

Multikultural di Indonesia merupakan realitas sosial yang tidak dapat diabaikan dalam lingkungan sosial masyarakat Indonesia. Secara sosial kultural, Indonesia memiliki masyarakat yang heterogen. Setiap daerah di Indonesia dari Sabang sampai Merauke mempunyai ciri khas budaya, tradisi, adat istiadat, etnis, ras, bahasa, dan agama yang berbeda beda. Indonesia bukanlah negara agama sekaligus bukan negara sekuler, karena secara prinsip setiap agama diperlakukan setara. Pancasila menghendaki nilai-nilai ketuhanan menjadi dasar bagi kehidupan bermasyarakat. Melalui penjelasan di atas dapat disimpulkan bahwa masyarakat memiliki kebebasan untuk memilih dan menganut agama maupun kepercayaan. Negara wajib mengakomodasi hak-hak para pemeluk agama, tidak ada perlakukan diskriminatif terhadap para pemeluk agama minoritas.

Keragaman masyarakat Indonesia menuntut rasa toleransi, menghormati, dan menghargai perbedaan tersebut. Kekayaan keragaman tersebut akan menjadi bumerang bila tidak dijaga dengan baik. Kekayaan keragaman berpotensi menimbulkan konflik akibat sentimen dan kecurigaan terhadap kelompok lain yang berbeda. Pendidikan dapat membantu membangun kesadaran untuk saling menghargai keragaman. Untuk membangun kesadaran kemajemukan kepada generasi muda, perlu adanya transformasi dalam dunia pendidikan. Kebutuhan pendidikan saat ini adalah penanaman nilai-nilai dan pemahaman multikulturalisme agar tercipta kehidupan masyarakat yang damai dan harmonis. Salah satu caranya adalah dengan menerapkan pendidikan multikultural di sekolah.

Seiring banyaknya permasalahan yang disebabkan oleh keragaman tersebut maka lahirlah pendidikan multikultural. Agus Salim (2006: 72) menjelaskan pendidikan multikultural bertujuan untuk meningkatkan rasa saling menghargai bagi semua kelompok budaya beserta mendapatkan kesempatan perlindungan hukum dan kesempatan memperoleh pendidikan yang sama. Pernyataan tersebut sesuai dengan yang tertuang dalam Undang-Undang (UU) Sistem Pendidikan Nasional (Sisdiknas) tahun 2003 Bab III Pasal 4 Ayat 1 menjelaskan bahwa "Pendidikan diselenggarakan secara demokratis dan berkeadilan serta tidak diskriminatif dengan menjunjung tinggi hak asasi manusia, nilai keagamaan, nilai kultural, dan kemajemukan bangsa".
Pendidikan multikultural menawarkan satu alternatif melalui penerapan strategi dan konsep pendidikan yang berbasis pada pemanfaatan keragaman yang ada di masyarakat, khususnya yang ada pada siswa, seperti keragaman etnis, agama, gender, status sosial, dan bahasa. Strategi pendidikan ini tidak hanya bertujuan agar siswa mudah memahami pelajaran tetapi juga meningkatkan kedasaran mereka untuk selalu berperilaku toleransi, humanis, pluralis, dan demokratis.

Penerapan pendidikan multikultural dapat diaplikasikan di semua mata pelajaran (Ainul Yaqin, 2005). Salah satunya adalah mata pelajaran Ilmu Pengetahuan Sosial. Pembelajaran IPS memiliki keterkaitan dalam penerapan pendidikan multikultural, walaupun sebenarnya pendidikan multikultural dapat diterapkan di semua mata pelajaran. Tujuan IPS yaitu untuk mempersiapkan peserta didik menjadi warga negara yang baik yang memiliki keterampilan, sikap, dan nilai agar dapat digunakan untuk memecahkan masalah pribadi maupun masalah sosial serta dapat mengambil keputusan dan berpartisipasi dalam masyarakat (Sapriya, 2012).

Salah satu sekolah yang menerapkan pendidikan multikultural adalah SMP Negeri 30 Semarang. SMP Negeri 30 Semarang yang berada di jalan Amarta No. 21 Kota Semarang ini memiliki beragam latar belakang yang beragam. berdasarkan hasil observasi awal yang dilakukan pada tanggal 27 Januari 2020, diperoleh keterangan dari Wakil kepala sekolah Yohanes Pujiyanto , menyatakan bahwa jumlah peserta didik yang beragama Islam sebanyak 707 , kemudian Kristen Protestan dan Kristen Katholik 56 dan yang menganut agama Hindu sebanyak 1 dari 764 jumlah peserta didik di SMP N 30 Semarang. Selain itu di sekolah tersebut ada satu kelas terdapat komposisi yang menarik dengan 16 peserta didik beragama Islam, 7 beragama Kristen Protestan, 9 beragama Kristen Katholik dan 1 peserta didik bergama Hindu. Hal tersebut merupakan suatu keunikan yang ada disekolah tersebut. Belum lagi dengan beragam asal daerah dari masing-masing peserta didik bukan cuma Jawa namu juga ada yang asli keturunan Bali, Sumatra, Kalimantan, dan bahkan keturunan ethnis China.

Melihat keberagaman yang terjadi di SMP N 30 Semarang sangatlah penting menerapkan Pendidikan Multikultural di sekolah tersebut agar dalam diri peserta didik muncul sikap saling menghargai dan menghormati peserta didik lain. Sehubungan dengan hal tersebut, Maka peneliti tertarik untuk melakukan penelitian dengan 
judul "Implementasi Pendidikan Multikultural dalam Pembelajaran Ilmu Pengetahuan Sosial di SMP N 30 Semarang"

Penelitian ini bertujuan untuk: (1) Mengetahui implementasi pendidikan multikultural dalam pembelajaran IPS di SMP Negeri 30 Semarang. (2) mengetahui apa saja faktor pendukung dan faktor penghambat implementasi pendidikan multikultural dalam pembelajaran IPS di SMP Negeri 30 Semarang.

Hasil penelitian ini, dapat menambah wawasan bagi peneliti sebagai calon pendidik, menambah wawasan bagi guru sebagai refleksi pelaksanaan pembelajaran IPS di kelas juga sebagai upaya guna menindaklanjuti pendidikan multikultural yang telah dilakukan. Penelitian ini juga diharapkan mampu sebagai upaya refleksi kebijakan yang diterpakan sekolah dalam penaman nilai multikultural di dalam pembelajaran IPS maupun melalui program program yang akan dilaksanakan oleh pihak sekolah maupun dinas pendidikan.

\section{METODE}

Penelitian ini merupakan penelitian merupakan penelitian Kualitatif Deskriptif. Metode kualitatif merupakan metode penelitian yang digunakan meneliti pada suatu kondisi obyek yang ilmiah, (sebagai lawannya adalah dengan eksperimen) dimana peneliti sebagai instrumen kunci, teknik pengumpulan data dilakukan secara triangulasi (gabungan), analisis dan bersifat induktif, dan hasil penelitian lebih menekankan makna daripada generalisasi (Sugiyono, 2016:1).

Latar penelitian ini yaitu SMP N 30 Semarang. Peneliti memilih SMP N 30 Semarang sebagai tempat penelitian karena keadaan sekolah yang sangat beragam sehingga sekolah tersebut sangat menarik jika dikaji dalam ranah pendidikan multikultural. Fokus penelitian ini yaitu implementasi pendidikan multikultural dalam pembelajaran IPS yang didalamnya mencakup perencanaan pembelajaran, pelaksanaan pembelajaran dan evaluasi pembelajaran. Lalu penelitian ini juga berfokus pada faktor pendukung dan faktir penghambat implementasi pendidikan multikultural dalam pembelajaran IPS di SMP N 30 Semarang.

Teknik pengumpulan data dilakukan dengan teknik observasi, wawancara, dokumentasi. observasi dilakukan peneliti dengan melakukan pengamatan dalam kegitan pembelajaran di kelas. Wawancara dilakukan untuk mendapat informasi dari Guru dan siswa untuk disinkronkan dengan hasil observasi. Dokumentasi untuk mengambil data baik gambar maupun dokumen-dokumen atau arsiparsip yang dimiliki sekolah.

\section{HASIL DAN PEMBAHASAN}

\section{Implementasi Pendidikan Multikultural dalam Pembelajaran IPS di SMP Negeri 30 Semarang}

SMP Negeri 30 Semarang merupakan sekolah yang terdiri dari peserta didik yang beragam latar belakang, seperti latar belakang agama. Sehingga menjadikan sekolah tersebut mempunyai pluralitas. Hal tersebut dibuktikan dengan keberagaman agama, banyak peserta didik yang memluk agama Katolik, Protestan dan bahkan terdapat pemeluk agama Hindu meskipun islam tetap mendominasi. Selain latar belakang agama sekolah ini juga memiliki perbedaan latar belakang kemampuan juga ada. Karena pernah ada juga anak berkebutuhan khusus (ABK) yang menempuh pendidikan disini. Implementasi pendidikan multikultural dalam pembelajaran IPS dibagi menjadi tiga tahap yakni perencanaan pembelajaran, pelaksanaan pembelajaran dan evaluasi pembelajaran.

\section{Perencanaan Pembelajaran}

Tahap perencanaan pembelajaran Guru membuat perangkat pembelajaran yang berupa program tahunan, program semester, silabus dan juga Rencana Perangkat Pembelajaran (RPP). Adapun lima komponen yang terdapat dalam silabus dan RPP yakni tujuan, materi, metode, media, dan evaluasi. Tujuan pembelajaran mencakup tiga ranah yakni ranah afektif, kognitif, dan psikomotorik. Materi yang dipilih dalam implementasi pembelajaran miltikultural adalah peristiwa nyata atau isu, masalah yang sedang terjadi dan yang terdapat di sekeliling lingkungan peserta didik. Seluruh materi dalam pembelajaran IPS mengambil berdasarkan peristiwa dan permasalahan yang terjadi. Metode yang digunakan adalah diskusi kelompok, tanya jawab, ceramah. Media yang digunakan oleh guru meliputi gambar-gambar visual, film, miniatur gunung, peta, globe. Dan terkadang juga menggunakan media hasil dari karya sendiri seperti video atau gambar hasil karya sendiri. Sedangkan evaluasi yang digunakan guru mengacu pada penilaian kognitif, afektif, dan psikomotorik. 


\section{Perlaksanaan Pembelajaran}

Pelaksanaan pembelajaran IPS yang menggunakan pendekatan multikultural terdapat beberapa hal yang harus dilaksanakan dalam pembelajaran. Diantaranya adalah sebagai berikut; 1) Menanamkan nilai untuk bersikap toleransi, menghargai dan menghormati keragaman; 2) Melatih peserta didik untuk memecahkan masalah-masalah sosial yang terjadi. 3) Materi yang diajarkan mengandung wawasan keragaman, peristiwa, dan permasalahan sosial. 4) Metode yang demokratis, kooperatif, dan bervariasi.

\section{Evaluasi Pembelajaran}

Evaluasi pembelajaran digunakan untuk mengukur kemampuan guru dalam mengajar dan kemampuan peserta didik dalam belajar. Evaluasi yang digunakan guru SMP Negeri 30 Semarang dalam menilai ranah kognitif sudah bervariasi dan menggunakan instrumen penilaian kognitif. Namun untuk menilai ranah afektif khususnya sikap multikultural peserta didik belum bervariasi, meskipun kurang bervariasi namun guru sudah tidak menggunakan teknik hafalan saja dalam menilai sikap afektif peserta didik dan menggunakan instrumen penilaian afektif. Evaluasi ranah psikomotorik dilihat dari ujian kompetensi yang dilaksanakan saat UTS dan UAS.

Faktor Pendorong dan Penghambat Implementasi Pendidikan Multikultural dalam Pembelajaran IPS di SMP Negeri 30 Semarang.

Faktor Pendorong pada Implementasi Pendidikan Multikultural dalam Pembelajaran IPS di SMP Negeri 30 Semarang

Faktor pendukung dalam pelaksanaan pendidikan multikultural dalam pembelajaran IPS di SMP Negeri 30 Semarang yaitu lingkungan dan iklim sekolah, materi dan metode pembelajaran, progam dan kegiatan sekolah, ekstrakurikuler (bakat dan minat), serta keasadaran peserta didik.

\section{Faktor Internal Dalam Pembelajaran IPS}

Faktor penghambat dalam implementasi pendidikan multikultural dalam pembelajaran IPS di SMP Negeri 30 Semarang yaitu; 1) Tidak semua materi IPS mengandung keragaman. Walaupun mata pelajaran IPS mempelajari tentang masyarakat dan lingkungan namun hanya beberapa materi IPS yang mengkaji tentang keragaman. 2) Minimnya media tentang keragaman. SMP Negeri 30 Semarang belum memilki banyak media yang berhubungan dengan keragaman seperti gambar. 3) Minimnya papan-papan maupun tulisan tentang keragaman. 4) Masih terdapat beberapa peserta didik yang mengejek temannya walaupun bukan mengejek tentang latar belakang peserta didik. 5) Adanya kondisi tidak terduga seperti pandemi Covid-19 menjadi penghambat dalam proses penguatan nilai- nilai multikultural. Sebab kegiatan belajar mengajar dilakukan secara daring yang menyebabkan tidak adanya interaksi langsung, guru biasanya juga memberikan materi lalu siswa harus mengerjakan tugasnya

\section{SIMPULAN}

Proses implementasi pendidikan multikultural dalam pembelajaran IPS di SMP Negeri 30 Semarang diawali dari perencanaan tujuan, materi, media, metode dan evaluasi yang nantinya akan digunakan saat pelaksanaan pembelajaran. Pelaksanaan pembelajaran bersifat terbuka, demokratis, dan berpusat pada peserta didik yang menekankan pada kesetaraan dan keadilan peserta didik serta menghargai masing-masing individu. Interaksi guru dan peserta didik saat pembelajaran juga berjalan dengan terbuka. Ketika pelaksanaan guru menyampaikan nilai dan sikap untuk mengakui, menerima, menghargai, menghormati dan bertoleransi dalam keragaman dan perbedaan. Evaluasi yang digunakan guru SMP Negeri 30 Semarang diranah kognitif sudah bervariasi.

Faktor pendorong implementasi pendidikan multikultural dalam pembelajaran IPS di SMP Negeri 30 Semarang yaitu: pertama, lingkungan dan iklim sekolah. kedua, materi dan metode pembelajaran. ketiga, program dan kegiatan sekolah. keempat, ekstrakurikuler (kegiatan minat dan bakat). kelima, kesadaran peserta didik.

Faktor penghambat implementasi pendidikan multikultural dalam pembelajaran IPS di SMP Negeri 30 Semarang diantaranya: pertama, tidak semua materi IPS mempelajari keberagaman. kedua, minimnya media tentang keberagaman. ketiga, Masih terdapat beberapa peserta didik yang mengejek temannya. keempat, minimnya papan-papan maupun tulisan tentang keragaman. kelima, kondisi tidak terduga. 


\section{DAFTAR PUSTAKA}

Salim, Agus. 2006. Stratifikasi Etnik Kajian Mikro Sosiologi Interaksi Etnis Jawa dan Cina. Yogyakarta: Tiara Wacana.

Sapriya, M. Ed, Prof. Dr. 2009. Pendidikan IPS Konsep Dan Pembelajaran. Bandung:PT Remaja Rosdakarya.
Sugiyono. 2007. Memahami Penelitian Kualitatif. Bandung: Alfabeta.

Yaqin, M. Ainul. 2005. Pendidikan Multikultural Cross Cultural Understanding untuk Demokrasi dan Keadilan. Yogyakarta: Pilar Media. 